\title{
BIOREMEDIATION OF Pb AND Cd METAL FROM INNER AMBON BAY SEDIMENT WHICH CONTAMINATED WITH HEAVY METAL USING Aspergillus niger
}

\author{
Yusthinus T. Male ${ }^{1 *}$, Cecilia A. Seumahu² ${ }^{2}$ Dominggus Malle $^{3}$ \\ ${ }^{1}$ Department of Chemistry, Faculty of Mathematics and Natural Sciences, Pattimura University \\ ${ }^{2}$ Department of Biology, Faculty of Mathematics and Natural Sciences, Pattimura University \\ ${ }^{3}$ Department of Animal Husbandry, Faculty of Agriculture, Pattimura University \\ *Corresponding author, e-mail: yusmale@fmipa.unpatti.ac.id
}

Received: Nov. 2019 Published: Jan. 2020

\begin{abstract}
Bioremediation is a method that use microorganism to extract heavy metal from contaminated waste. In this research Aspergillus niger was used to extract heavy metal such as $\mathrm{Pb}$ and $\mathrm{Cd}$ of marine sediment from Waiheru shore, Inner part of Ambon Bay, which was detected as significantly high heavy metal contaminated site among seven sites. Bioremediation were done using Aspergillus nigers to extract $\mathrm{Pb}$ and $\mathrm{Cd}$ metal from sediment, then their solubility being measured in filtrate media. Result shows that $\mathrm{Cd}$ metal were only detected 15 days after incubation while $\mathrm{Pb}$ were detected since the first day incubation. This result also showing the fluctuating solubility of $\mathrm{Pb}$ metal. It is suspected that this occurs due to biosorption ability of the fungi that being used which triggers metal accumulation in the cell structure. It is therefore can be concluded that Aspergillus niger can be used in bioremediation of sediment that are being contaminated by $\mathrm{Pb}$ and $\mathrm{Cd}$ heavy metals.
\end{abstract}

Keywords: Ambon Bay, bioremediation, Aspergillus niger, metal, $\mathrm{Pb}, \mathrm{Cd}$.

\section{INTRODUCTION}

Coastal towns and industries, together with power stations, have historically discharged their waste either directly into the sea, or into estuary which then quickly reaches the sea. In more recent times sewage effluent is treated to a reasonable standard before direct discharge, but most storm water drains, which are most highly polluted, discharged directly with no treatment at all. Storm water from industrial and urban areas has been identified as a source of organic and inorganic pollution (Reichelt-Brushett, 2012). High oil concentration, and metal concentration including zinc, lead, nickel, mercury, copper and chromium in sediments and organisms have been related to discharge from both industrial and urban areas.

High lead concentrations in waters around urban areas have been attributed to the combustion of lead petrol. Sadiq (1992) suggests that as the consumptions of leaded petrol products decreases, will decreases the lead concentrations. Agricultural runoff often consists of a combination of contaminants including fertilizers, pesticides (halogenated hydrocarbons) and hydrocarbon pollutants. There are several sources of trace metals in agricultural runoff. Phosphate fertilizers contain 5-10 $\mu \mathrm{g} / \mathrm{g}$ of cadmium, and the cadmium concentration is directly correlated with the amount of total phosphorus in the fertilizer (O’Neil, 1985, Logantahan et al., 1997).

Inner part of Ambon Bay (Teluk Ambon bagian Dalam-TAD) is the traffic lanes and port for many ships and ferry. Ambon Bay also became a big pond for effluent, plastic, organic, chemicals and many wastes from domestic and industrial activity in those area. Some of toxic heavy metals were accumulated in sediments, e.g. $\mathrm{Cd}, \mathrm{Pb}, \mathrm{As}$, and $\mathrm{Hg}$ (Widowati et al., 2008). River and bay sediments were proportionately higher in available mercury than elemental mercury (Male et al., 2013). Cadmium (Cd) and Lead (Pb) are heavy metals that are harmful to human health so that the US-EPA (United States Environmental Protection Agency) establish maximum levels of metal in sediment for was $5 \mathrm{ppm}(\mathrm{mg} / \mathrm{L})$ for $\mathrm{Cd}$ and $15 \mathrm{ppm}$ for $\mathrm{Pb}$. Anthropogenic sources of $\mathrm{Cd}$ metal were paints, pigments, plastic stabilizers and waste from metal coating industries whereas $\mathrm{Pb}$ metal comes from burning leaded fuel, battery waste, insecticides and herbicides (Dixit et al., 2015). 
To reduce the heavy metal content in the sediment, some method can be used, including remediation. Conventionally, the remediation of heavy metal contaminated objects can be done with excavation and solidification/stabilization. Although this technique is sufficient to maintain the amount of pollutants, it does not dispose of heavy metals well so that heavy metals still present in contaminated objects (Yanga et al, 2009). Chemical extraction with strong acids, chelators or organic acids can also be used to extract heavy metals from contaminated objects (Peters, 1999). Fungi are organisms that can be exploited as heavy metal bioremediation agents because the fungi are capable of producing large amounts of organic acids in large quantities, the fungus is able to withstand large $\mathrm{pH}$ vulnerabilities and even fungi have high tolerance limits for heavy metal contamination (White et al., 1997; Iram et al., 2012).
The sampling focus was in the inner part of Ambon Bay which associated with domestic, industrial and agriculture activity. Samples of marine sediments were collected from seven sites around TAD by van Veen grab at deeper marine locations (Figure 1). Samples were stored in polyethylene bags and transported on ice to the Inorganic Chemistry Laboratory, University of Pattimura, where they were immediately frozen. Samples were dried at $60{ }^{\circ} \mathrm{C}$, ground then thoroughly homogenized and kept in a silica gel desiccator until analyzed. All glassware and other containers were soaked in $10 \% \mathrm{HNO}_{3}$ for $24 \mathrm{~h}$ and rinsed three times with deionized water prior to use. Samples were weighed into separated 100 $\mathrm{mL}$ beaker glass and digested using aqua regia (5.0 mL HNO $3: 15 \mathrm{~mL} \mathrm{HCl})$ on hotplate at $140{ }^{\circ} \mathrm{C}$ for one hour. After cooling, the solution was filtered with Whatman no.1 filter paper and diluted with deionized water to $25 \mathrm{~mL}$ in

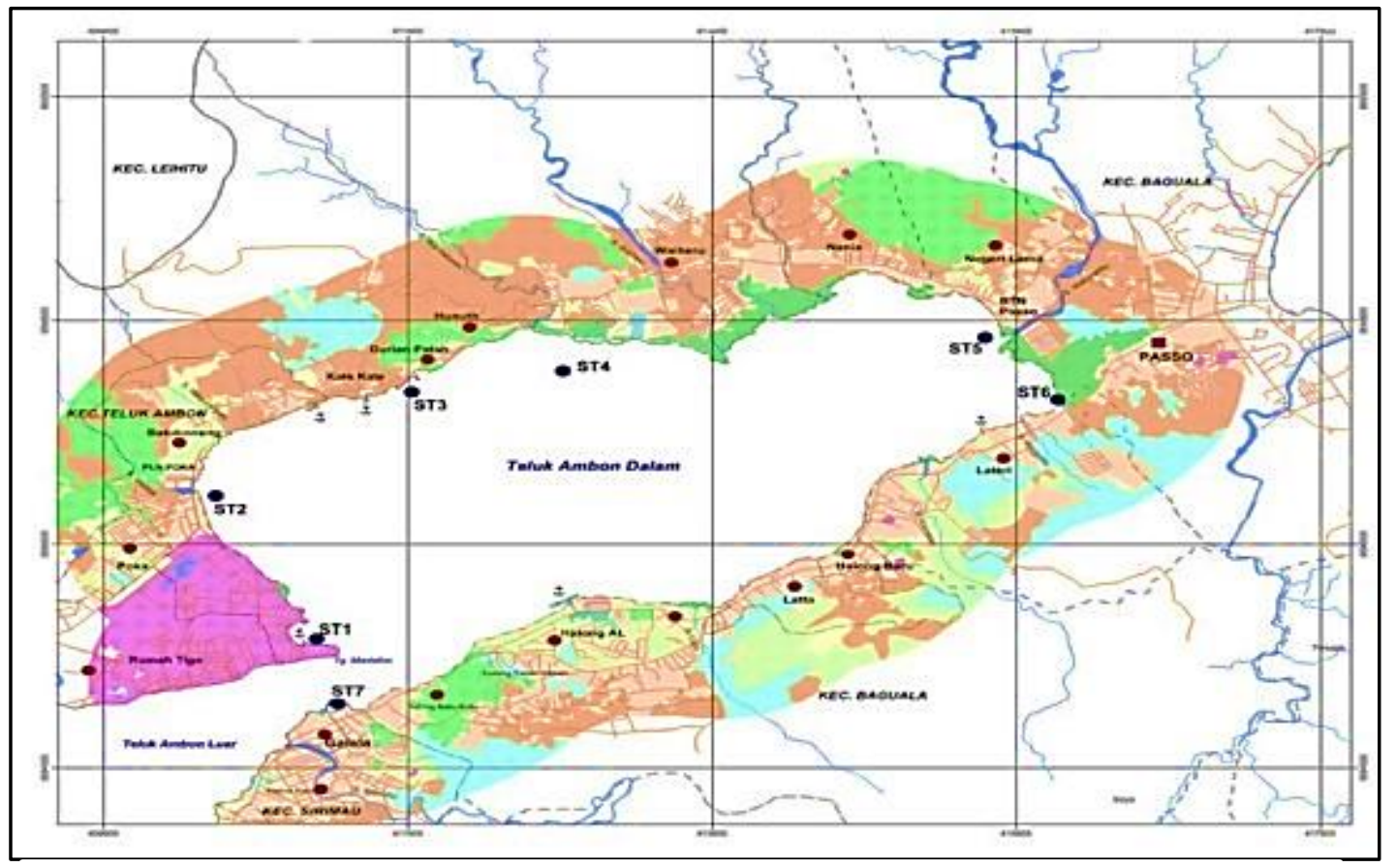

Fig. 1. The map of the inner part of Ambon Bay (TAD) with the sampling sites

Aspergillus is one of the fungi who have the ability to reduce the heavy metals concentration (Congeevaram et al., 2006). Aspergillus niger has been reported to be capable of removing lead, cadmium, copper and nickel ions in wastewater (Kapoor et al., 1998). She-Bardan et al. (2012) reported that Aspergillus fumigates is capable of producing oxalic and citrate acids capable of removing $\mathrm{Pb}$ from contaminated soils of heavy metals. volumetric flask. Solution then transferred to 30 $\mathrm{mL}$ polypropylene vials, stored in fridge prior to analysis with AAS (Atomic Absorption Spectroscopy).

The results of $\mathrm{Pb}$ and $\mathrm{Cd}$ concentrations in sediments are show that from the seven sampling sites, the sediments in the Waiheru marine waters contain the highest levels of $\mathrm{Pb}$ and $\mathrm{Cd}$ metals. This result is supported by sediment type analysis where sediment on Waiheru marine waters is 
dominated by silt and clay which has high affinity to heavy metals (Male et al., 2017).

The availability of heavy metals in sediments is closely related to the nature and size of the sediments. Sediments containing clay and organic quantities will tend to accumulate higher metals, since they have binding properties (Arifin et al., 2006). The size of sediment particles (grain size) is one of the factors that influence concentration and heavy metal adsorption process in sediment. The affinity of heavy metals is generally greater in finer sediments, so that heavy metal concentrations are larger on the surface of sediments having smaller particle sizes (Parera, 2004). The highest concentrations of heavy metals are found in sediments in the form of mud, clay, muddy sand or mixtures of the three compared to pure sand (Schaule and Patterson, 1981).The purpose of this study was to investigate the separation of heavy metals from contaminated sediments with bioremediation (bioleaching) methods using Aspergillus niger fungi.

\section{METHODOLOGY}

\section{Experimental Details}

\section{Standard Curve of $\mathrm{Pb}$ and $\mathrm{Cd}$}

From stock solution of $\mathrm{Pb}$ and $\mathrm{Cd}(1.000$ ppm), $10 \mathrm{~mL}$ of each solution were transferred $100 \mathrm{~mL}$ volumetric flasks and diluted with deionized water. From the new stock solutions (100 ppm), $10 \mathrm{~mL}$ of each solution were transferred $100 \mathrm{~mL}$ volumetric flasks and diluted with deionized water to make $10 \mathrm{ppm}$ stock solution. To obtain working solutions with each concentration was $0.1 ; 0.2 ; 0.3 ; 0.4$ and $0.5 \mathrm{ppm}$ respectively, $1 \mathrm{~mL}, 2 \mathrm{~mL}, 3 \mathrm{~mL}, 4 \mathrm{~mL}$ and $5 \mathrm{~mL}$ from $10 \mathrm{ppm}$ stock solution were transferred into single $100 \mathrm{~mL}$ volumetric flasks and diluted with deionized water prior to analyzed with AAS.

\section{Preparation of microorganisms}

The microbes used are Aspergillus niger from the moldy copra that has been provided from the Microbiology Laboratory, F-MIPA Unpatti. Potato Dextrose Agar (PDA) was used as a growth medium for Aspergillus niger fungi. Some of $100 \mathrm{~g}$ of potatoes that have been peeled and washed and then diced then boiled with $500 \mathrm{~mL}$ deionized water and filtered. Then add $10 \mathrm{~g}$ dextrose and the aqueous mixed medium added to the volume of $500 \mathrm{~mL}$. The medium is then fed into a $500 \mathrm{~mL}$ erlenmeyer and capped with cotton, then sterilized using an autoclave at $121^{\circ} \mathrm{C}$ with $1 \mathrm{~atm}$ pressure for 15 minutes.

\section{Bioleaching of $\mathrm{Pb}$ and Cd Metals from Sediments}

After aspergillus niger inoculant was growth for 7 days, inoculant was added in spore form into $250 \mathrm{~mL}$ liquid medium Potato Dextrose Broth (PDB) as nutrient and $2 \mathrm{~g}$ fine sediment samples. Medium contains samples was transferred into a $500 \mathrm{~mL}$ erlenmeyer flask and incubated at $37^{\circ} \mathrm{C}$ for $0,5,10$ and 15 days. After the bioleaching process was finish, the sample were centrifuged at $2200 \mathrm{rpm}$ for 10 minutes then filtered to separate the filtrate and residue prior to filtrate was analyzed with AAS.

\section{RESULTS AND DISSCUSION}

\section{Bioleaching of $\mathbf{P b}$ Metal}

The concentration of $\mathrm{Pb}$ metal as product of bioleaching process are shown in Figure 2. Based on the Figure 2 it can be seen that from the 1st day until the 5th day, there was an increase of dissolved lead metal concentration $(\mathrm{Pb})$. At $1^{\text {st }}$ day, concentration of lead metal $(\mathrm{Pb})$ was 6.825 $\mathrm{mg} / \mathrm{kg}$ and on the $5^{\text {th }}$ day became to $36.775 \mathrm{mg} / \mathrm{kg}$. In the bioleaching process, the concentration tends to increase linier to bioleaching period. The effectiveness of the bioleaching process depends on the ability of microorganisms and the mineral and chemical composition of the extracted metal (Zhang et al., 2008).

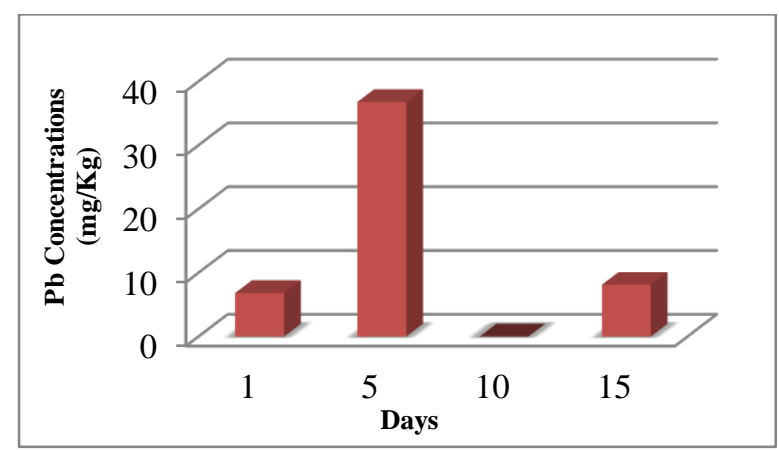

Fig. 2. The result of bioleaching $\mathrm{Pb}$ Metal

Concentration of $\mathrm{Pb}$ metal at the $1^{\text {st }}$ day until the 10th day greatly decreased. This differs considerably from the concentration on the 5th day. According to Iskandar et al. (2011), Aspergillus niger tend to bioacumulate $\mathrm{Pb}$ up to $54 \mathrm{mg} / \mathrm{g}$ of mycelium. In this study, $\mathrm{Pb}$ detection was not detected in mycelium but most likely that 
$\mathrm{Pb}$ was accumulated in the cell structure so that the amount of dissolved $\mathrm{Pb}$ decreased.

This results also shows that fluctuations in $\mathrm{Pb}$ concentration occur because the process was done using non-sterile sediments so it possible for contaminated with other microorganisms which influence the biosorption and bioleaching processes (Sabra et al., 2012). Factors affecting the bioleaching process was nutrition, oxygen demand, $\mathrm{pH}$ and temperature as well as types of microorganisms that can increase or inhibit the bioleaching process (Kurniawan et al., 2011).

\section{Bioleaching of Cd Metal}

Concentration of $\mathrm{Cd}$ metal which extracted from Waiheru marine sediments is shown in Figure 3. Concentration of $\mathrm{Cd}$ metal at $15^{\text {th }}$ days was $0.0249 \mathrm{ppm}$ while at $0,5^{\text {th }}$ and $10^{\text {th }}$ days was not detected. This happens because fungi can accumulate heavy metals. Fazli et al. (2015) have reported that Aspergillus versicolor and Aspergillus fumigates were able to accumulate $\mathrm{Cd}$ in cell structures with amounts greater than $7.0 \mathrm{mg}$ and $5.0 \mathrm{mg}$ respectively per $1 \mathrm{~g}$ of mycelium. In addition, another factor that is suspected to be influential is also the concentration of $\mathrm{Cd}$ weight metal which is found also very low compared to other heavy metals so that during bioleaching process, citric acid produced from Aspergillus niger is more easily dissolved other metals contained.

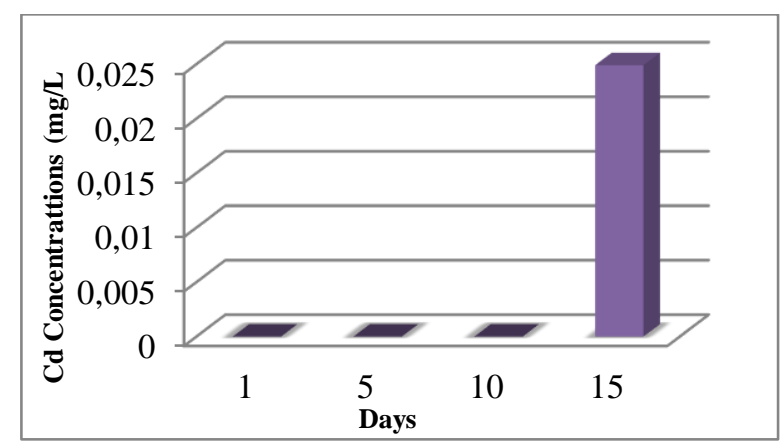

Fig. 3. The result of bioleaching Cd Metal

Aspergillus niger fungi, organic acids produced greatly affect the solubility of heavy metals. She-Bardan et al. (2012) also observed that Aspergillus fumigates was able to release $88 \% \mathrm{~Pb}$ through a two-stage process in the presence of citric acid production as the dominant acid. Zeng et al. (2015) even uses Aspergillus niger to perform heavy metal bioleaching in contaminated sediments and found that $\mathrm{Cd}$ metal is capable of removing with a $99.5 \%$ extraction efficiency through a two-stage process. This occurs because in the two-stage process, organic gluconic acid and succinate are produced in greater quantities than the one-stage process.

\section{CONCLUSION}

Aspergillus niger can be used to extract $\mathrm{Pb}$ and $\mathrm{Cd}$ heavy metals in marine contaminated sediment. Fluctuations in extract concentrations are due to the ability of fungal accumulation in cell structure and the use of non-sterile sediments that allow biosorption and bioleaching by other microorganisms.

\section{ACKNOWLEDGMENTS}

This research was funded by Pattimura University through the scheme of Penelitian Unggulan Daerah 2017 under contract number: 08.74.2H /SPK-PJ /UN13-PPBJ /PUDLP2M/2017.

\section{REFERENCES}

Arifin, Z., D. Hindarti, T. Agustini, P. Widiawanwari, E. Matondang, Purbonegoro, T., 2006, Nasib Kontaminan Logam dan Implikasinya pada Komunitas Bentik, Penelitian Kompatitif-LIPI. Laporan Akhir, P2O-LIPI, Jakarta.

Congeevaram, S., Dhamarani, S., Park, J., Dexilin, M., Thamaraiselvi, K., 2006, Biosorption of Chromium and Nickel by Heavy Metal Resistant Fungal and Bacterial Isolates, School of Civil and Environmental Engineering, Seoul: Yonsei University, 120749.

Dixit A., Dixit, S., Goswami, C.S., 2015, Ecofriendly Alternatives for The Removal of Heavy Metal Using Dry Biomass of Weeds and Study the Mechanism Involved, J. of Bioremed. and Biodegrad., 6(3), 2-7.

Fazli, M.M., Soleimani, N., Mehrasbi, M., Darabian, S., Mohammad, J., Ramazani, A., 2015, Highly Cadmium Tolerant Fungi: Their Tolerance and Removal Potential, $J$. Env. Health Sci. and Eng., 13 (19), 1-9.

Iram, S., Parveen, K., Usman, J., Nasir, K., Akhtar, N., Arouj, S., Ahmad, I., 2012, Heavy Metal Tolerance of Filamentous Fungal Strain Isolated from Soil Irrigated with Industrial Waste Water, Biologija, 58(3), 107-116. 
Iskandar, N., Zainudin, N. A., Tan, S. G., 2011, Tolerance and Biosorption of Copper $(\mathrm{Cu})$ and Lead $(\mathrm{Pb})$ by Filamentous Fungi Isolated from A Freshwater Ecosystem, J. Environt. Sci. (China), 23(5), 824-830.

Kapoor, A., Viraraghavan, T., Cullimore, D. R., 1998, Removal of Heavy Metals Using the Fungus Aspergillus niger, Regina Water Research Institue, Canada: University of Regina.

Kurniawan, R., Juhanda, S., Banimulyanti, V., 2015, Aplikasi Bioleaching Dalam Pemisahan Logam dari Batuan Mineral Pyrite dengan Menggunakan Bakteri Thiobacillus ferooxidans dan Fungi Aspergillus niger, Prosiding Seminar Nasional Pengembangan Teknologi Kimia untuk Pengolahan SDA, Yogyakarta.

Logantahan, P., Hedley, M.J. Donward, 1997, Movement of Cadmium and Phosphorus from Phosphatic Fertilizers in A Pasture Soil in New Zealand, Environt. Poll., 95, 319324.

Male, Y.T., Brushett-Amanda J.R., Pocock, M., Nanlohy, A., 2013, Recent Mercury Contamination from Artisanal Gold Mining on Buru Island, Indonesia-Potential Future Risk to Environmental Health and Food Safety, Marine Poll. Bull., 77, 428-433.

Male, Y.T., Malle, D., Bijang, C.M., Fransina, E.G., Seumahu, C.A., Dolaitery, M.L., Landu, S., Gasperz, N., 2017, Analisis Kadar Logam Cadmium (Cd) dan Timbal (Pb) pada Sedimen di Teluk Ambon bagian Dalam, Indo. J.Chem. Res., 5(1), 434-443.

O'Neil, P., 1985, Environmental Chemistry, Willey \& Son, London: George Allen and Unwin Ltd. 232

Parera, P., 2004, Heavy Metal Concentrations in the Pacific Oyster; Crassostrea gigas, Thesis, Auckland University of Technology, Auckland.

Peters, W. R..1999, Chelant Extraction of Heavy Metals from Contaminated Soils. J. of Hazardous Materials, 66(1), 151-210.
Reichelt-Brushett, A., 2012, Pollution of The Marine Environment, Study Guide, Southern Cross University, Australia.

Sabra, N., Dubourguier, H., Hamieh, T., 2012, Fungal Leaching of Heavy Metals from Sediments Dredged from The Deule Canal, France, Adv. in Chem. Eng. and Sci., 2, 1-8.

Sadiq, M., 1992, Toxic Metal Chemistry in The Marine Environment, New York: Marcel Dekker, 390.

Schaule, B. K., Patterson, C.C., 1981, Lead Concentrations in The Northeast Pacific: Evidence for Global Anthropogenic Perturbations, Earth and Planetary Sci. Letters, 54(1), 97-116.

She-Bardan, B. J., Othman, B., Wahid, S. A., Husin, A., Sadegh-Zadeh, F., 2012, Bioleaching of Heavy Metals from Mine Tailings by Aspergillus fumigates, Bioremed. J., 16(2), 57-65.

White, C., Sayer, J. A., Gadd, G. M., 1997, Microbial Solubilization and Immobilization of Toxic Metals: Key Biogeochemical Processes for Treatment of Contamination, Microbiology Res., 2, 503-516.

Widowati, W., Sastiono, A., Raymond, J, R., 2008, Efek Toksik Logam: Pencegahan Dan Penanggulangan Pencemaran, Penerbit Andi, Yogyakarta.

Yanga, J. S., Leea, J. Y., Baekb, K., Kwonc, T. S, Choi, 2009, Extraction and Behavior of As, $\mathrm{Pb}$, and $\mathrm{Zn}$ From Mine Tailings with Acid and Base Solutions, J. Hazard Mater, 171, 443-451

Zeng, X., Wei, S., Sun, L., Jacques, D. A., Tang, J., Linn, M., Ji, Z., Wang, J., Zhu, J., Xu, Z. 2015, Bioleaching of Heavy Metals from Contaminated Sediments by Aspergillus niger Strain SY1, J. Soils Sediments, 15, 1029-1038.

Zhang, Lin., Qiu Guan-Zhou. 2008, Bioleaching of Pyrite by A. ferrooxidans and L. ferriphilum. Changsa, School of Minerals Processing and Bioengineering, Central South University, China. 